\title{
Implementation of Marriage in the Period of Armed Conflict
} in Aceh

\author{
Munawar Khali1 ${ }^{1}$, Pagar $^{2}$, M. Jamil ${ }^{3}$ \\ ${ }^{1}$ Ph.D Student in State Islamic University of North Sumatera (UINSU), Medan, Indonesia \\ ${ }^{2,3}$ Lecturer in in State Islamic University of North Sumatera (UINSU), Medan, Indonesia \\ Email: munawar.khalil.1sm@gmail.com
}

\begin{abstract}
:
This study deals with implementation of marriage in the period of armed conflict in Aceh. The marriage process during the armed conflict did not receive pre-marital guidance services nor was the registration of marriage carried out because the situation was uncertain. However, this situation is not an obstacle to the sustainability of marriage in the Acehnese society in an orderly and orderly manner. The sample of the study is North Aceh District which is the area that has the greatest influence of armed conflict between 1999 and 2005 and it also the region with the highest escalation of violence during the armed conflict, many areas in North Aceh controlled by GAM. The result shows that the implementation of the marriage which took place in the period between 1999 and 2005 was generally not administered in accordance with the prevailing laws and regulations because the Registrar of Marriage Officer did not dare to carry out their duties and functions as a public servant in checking the administration of marriage and recording it in accordance with the mandate, moreover the community is also afraid to deal with government offices.
\end{abstract}

Keywords :

marriage; armed conflict; Aceh

\section{Introduction}

Marriage is a necessity for humans, because only through marriage someone will get a balance of life both biologically and psychologically. Likewise divorce is the last effort in resolving conflicts that occur in the household, where the husband and wife are no longer able to exercise their respective rights and obligations, so divorce is an emergency door that must be used to get out of trouble (masyaqqah) to live in a house stairs. Therefore, this underhand marriage creates legal uncertainty based on the laws and regulations in force in the Republic of Indonesia.

Even though during the armed conflict people in Aceh needed legal institutions to carry out marriages and divorces normally as stated in the marriage law. However, the KUA and the Religious Courts (Mahkamah Syar'iah) at that time could be said to be unable to carry out activities as appropriate as judicial institutions in other regions in Indonesia. Given the need or need for legal institutions at that time in the very urgent category. But the state of armed conflict has undermined the desire of the Acehnese to organize marriages in the KUA as mandated by the applicable law. Even though through marriage each individual can obtain peace (sakinah), love (mawaddah) and affection (rahmah).

The implementation of marriage in one country, region or community is regulated by legislation, therefore marriage is recorded by state institutions so that the marriage is considered valid. However, it is seen according to Islamic jurisprudence that marriage is considered valid if it fulfills the conditions set by the Shari'a. According to the laws of the 
Republic of Indonesia concerning marriage, it has been mentioned in Article 1 of Law Number 1 of 1974, namely; marriage is an inner and outer bond between a man and a woman as husband and wife with the aim of forming a happy and eternal family or household based on the One Godhead. Article 2 paragraph (1); marriage is legal if carried out according to the laws of each religion and its beliefs and (2); each marriage is recorded according to the applicable laws and regulations.

Based on the fact that the needs of the Acehnese people towards the KUA and the Religious Courts / Mahkamah Syar'iyah are assumed that the need for marriage is a biological, psychological and social demand. When viewed from language, marriage implies intercourse, where marriage is a road that justifies intercourse (sex) between men and women. Indeed, through marriage humans can channel their biological needs. The regulation of marriage as stipulated in the laws of the Republic of Indonesia is to guarantee the establishment of a social system in the life of the state and nation.

\section{Review of Literatures}

\subsection{The Marriage Paradigms of Sociological Perspective}

The marriage paradigm of sociological perspectives is described to reinforce the basics of culture and norms about marriage in general. The sociological theory that discusses marriage has developed rapidly in the 19th century. This theory was developed by several Western sociologists such as MacIntyre, Komarovsky and Waller. Based on the family sociology theory, the element of marriage has also been discussed extensively which recommends that marriage be a family formation consisting of a number of family members while having their respective duties. Family institutions besides functioning as social institutions formed through marriage are stated to be closely related to the fulfillment of sexual needs between men and women. If one partner then does not succeed in carrying out his biological function, it is possible for a family disorder to occur which usually leads to divorce and polygamy. Marriage is also seen as an institution that can socialize the values and personal formation of generations. Socialization means doing a learning process for members in family institutions.

Besides that, through the marriage process of a family institution formed as well as a family institution it functions to channel love and love. Love needs are a very important requirement for someone who is expected to be played by the family. Sociologists have formulated that family institutions function to educate generations. In that case it can be seen from the growth of a child starting from a baby, learning to walk until he is able to walk. Religious function in the family is one of the main indicators of the establishment of religion in the social environment. Even the family is a social institution that is very important for the continuity of human civilization. From the sociological perspective, the family institution consists of a nuclear family. Inner family is a group consisting of father, mother, and children who have not separated themselves and formed their own family. Although other families cannot be separated from the emphasis on the relationship between the families of the household where he lives. On the other hand, the extended family or extended family consists of all people of the same grandfather and grandmother, including the descendants of each wife and husband. The term broad family is often used to refer to the family of families and other families who have good relations with him and still maintain and maintain the relationship. Family is the first social group in social life. 


\subsection{Marriage Legislation in Indonesia}

Indonesia is a legal state that strongly promotes legal philosophy to unite people in one frame of the nation, one unit, one language, and family principles, even though the follow-up of laws created is often a hybrid (mix), especially from Islamic law, customary law, and western law (civil law / especially the Dutch state) Islamic law is often used as the basis of legal philosophy as a reference given that the majority of Indonesia's population are Muslims. Renewal in family law in the Muslim world is characterized not only by the substitution of Islamic family law with Western laws, but also by changes in Islamic law itself based on reinterpretation (reinterpretation) of Islamic law in accordance with the development of reasoning and practice. It is through this way that family law in the Muslim world changes. The main purpose of family law reform is to improve the status or position of women and strengthen the rights of family members. Discussion of gender issues and their impact on the development of Islamic law which focuses on the issue that family law reform in the Muslim world aims to protect and improve the status of women.

Likewise, the history of family law in Indonesia is also inseparable from the origins of the Religious Courts in Indonesia, which can be traced from the head or head of regional mosque administration, which deals with family affairs and inheritance from the Colonial Government since the 16th century. At that time the Religious Courts were carried out in the porch of the mosque and its decision was based on the Shafi'i school. In 1882 a decree was issued which established the court in its present form.

\subsection{Marriage in the Aceh Community Cultural Perspective}

In the context of Acehnese culture, marriage is discussed to explain the stages and processes that are practiced in Acehnese society downwardly. Traditional practice of marriage from generation to generation by the people of Aceh is relevant to Islamic law. Indeed, this marriage tradition is believed to be related to Islam which is known to have been traced in Aceh since the 8th / M century. As in general in the Indonesian society the marriage process through preparations must be made. To find a mate for a boy who is considered an adult, the family will send a person who is thought to be wise in speaking known as a term. If you have got the girl in question, then she will first review the girl's status. If no one has yet, then he will convey the intention to propose to the girl.

This procession is usually carried out directly by parents or special envoys from men. In addition to getting to know family and prospective brides, this procession is also carried out to interact with each other and introduce themselves to the bride's family. For the second stage, it is usually continued with jak ba ranub ${ }^{1}$. In this procession, the male family sent his envoy to visit the family of the woman by bringing souvenirs such as betel, cake and others. During the visit the envoy revealed the purpose and purpose of their arrival to the female family. If accepted, it will be followed by deliberations with the two families and will be continued with jak ba tanda ${ }^{2}$. The items which carried by the messenger are placed in the talam or dalong which have been decorated and handed over to the women. On the day that had been agreed upon, a group of people from the male side came to the girl's parents' house by carrying betel as a reinforcement of the bond and its contents. After that, it will then be followed by a discussion about dowry, day and date, and invitations or guests who will come at the wedding ceremony. After the application is over, the man will beg for leave to go home

\footnotetext{
${ }^{1} \mathrm{Jak}$ ba ranub is a procession to propose brides

${ }^{2} \mathrm{Jak}$ ba tanda is a procession of strengthening the sign. Men will bring betel, food, a set of clothes, signs and jewelry.
} 
and the woman's family asks for time to consult with her daughter about whether or not the application is accepted.

\section{Research Methods}

With regard to the title of this study "Implementation Marriage in the Period of Armed Conflict in Aceh", the location of the study was the place where research was carried out to identify the implementation of marriage during the armed conflict in Aceh. The selection of the Aceh Province as the location of this study has several academic reasons: the existence of armed conflict in the period of 1998 until the MoU was signed in Helsinki on 15 August 2005 relating to the object of research on the implementation of marriage during the armed conflict in Aceh, besides that there was a declaration from the GAM commander from several regions not to relate well in the form of administrative relations or in other matters with government offices. This situation has caused civil service offices to be paralyzed because employees did not dare to carry out activities to provide services to the community for fear of getting into trouble with the conflicting parties. Considering the vastness of the Aceh Province and the number of regencies / cities, to facilitate research there are 2 out of 23 regencies / cities as research sample locations that are considered to represent Aceh as a whole.

North Aceh District, with consideration: North Aceh is a vast and most populated area compared to other regencies / cities in Aceh, also the region which has the greatest influence of armed conflict between 1999 and 2005, besides that the district of North Aceh is one of the Regencies the strongest GAM base, and also the region with the highest escalation of violence during the armed conflict, many areas in North Aceh were controlled by GAM so that it could be suspected that the activities of civil government offices were almost nonexistent at that time. Therefore, North Aceh Regency is made as a sample for research on marital management which is expected to be able to represent other Districts / Cities in the matters mentioned above.

\section{Discussion}

Marriage is the beginning of the meeting of two people to bind between men and women in the long term which includes sharing and gaining normal life. Bachtiar said that marriage is the door to the meeting of two hearts in the shade of life to get a decent, happy, harmonious life and get offspring. Marriage can be understood as a binding agreement between men and women as well as binding or establishing harmony between two family institutions. According to Article 1 of the Marriage Law of 1974, the purpose of marriage is to form a happy and eternal family based on the One Godhead.

From the aspect of the sociology of marriage, it provides several important benefits for the survival of human beings, even though marriage, it can guard the offspring and maintain the dignity and dignity of the human race, including forming social institutions and functioning as the heirs of culture. As is commonly known, marriage is an activity of male and female individuals which aims to bind relationships inwardly and inwardly. Through the bond of marriage, the basic human needs, be it psychological needs or biological needs can be channeled. Therefore, marriage is a basic human need that cannot be stopped due to natural disasters or conflicts and so forth.

The process and procedure for organizing a marriage that will enter marriage according to Islam is before someone (prospective bridegroom) decides to marry someone (prospective bride) to become his wife, Islam recommends asking for consideration from a 
close relative of the woman who is good in religion and know very well about the matter of the woman who will be proposed by the prospective bridegroom. This is important so that he can give honest and fair consideration. Likewise for the prospective bride who is applied by a man, then he also needs to ask for consideration from a close relative who is good in religion.

Although the two prospective brides have asked for consideration from relatives who have a good understanding of their religion, Islam also recommends that both (prospective bridegrooms / brides) to perform istikharah prayer to obtain guidance or determination. This istikharah prayer is done to get the determination of the heart while avoiding the possibility of falling into the suffering of life. If the prospective man has got the steadiness in making his choice, then let him immediately ask for his hand by facing the parents / guardians of the woman of his choice to convey his will, which is asking to be blessed to marry his child. If the above process has been carried out and the proposal has been approved by the parents / guardians and prospective brides (the liking of the two bride and groom), then the marriage contract is carried out with the obligation to pay dowry in addition to witnesses, with too many stages the above stage then ends with Walimatul Ursy. Thus it is clear that the administration of marriage has been arranged in Islamic syrai'at in detail and in detail.

Aside from the Shari'ah provisions as a guideline in fostering a household there are also provisions that are al-Wadh'i also defined by tawtsiqy is an additional rule with the aim that marriage in the Islamic ummah is not wild, but recorded in the marriage certificate register made by which is authorized for that which is regulated in state administrative regulations. Its use so that a marriage institution which is a very important and strategic place in Islamic society can be protected from negative efforts from irresponsible parties. For example, as an anticipation effort from the denial of a marriage contract by a husband in the future, although basically it can be protected by witnesses, but of course it will be more protected by the official registration in the authorized institution for that. According to the Marriage Act of the Arab Republic of Egypt Number 78 of 1931 stated that there would be no complaints about marriages or matters based on marriage, except based on the official declaration of marriage. However, according to the fatwa of Jad al-Haq Ali Jaad al-Haq, as cited by Satria Effendi, without fulfilling the laws and regulations, the marriage was considered legitimate if it had completed all the conditions and harmoniously as stipulated in Shari'at Islam.

The Fatwa of Sheikh Al-Azhar, does not mean that someone may arbitrarily violate the laws in a country, because in his fatwa he still reminded the importance of marriage enumeration, he reminded that marriage is recorded according to the applicable laws and regulations, also confirmed that the rules and regulations governing marriage are things that must be done by every Muslim who holds a marriage, in anticipation of the need to deal with a judicial institution. For example, if in the future one of the husband and wife denies the marriage or denial comes when dividing the inheritance among the heirs.

Wahbah Al-Zulaily in his work Al-Fiqh Al-Islami wa Adillatuhu, expressly divides the marriage requirements into the sharia requirements and tautsiqy requirements. The condition of syar'i is a condition regarding the validity of a legal event depending on it, which in this case is the pillars of marriage with the conditions specified. While the tawtsiqiy condition is a formulated to be used as evidence of the truth of an action as an effort to anticipate future obscurity. Tawtsiqiy's requirements do not relate to the legal requirements of an act, but as evidence of an act. For example, the presence of two witnesses in each form of transaction is 
a tawtsiqiy condition, except the presence of two witnesses in the marriage engagement is a sharia condition, because it is the forming element of the marriage procession and which determines the legal or invalid marriage event, besides as a tawtsiqiy condition. ${ }^{3}$

In the implementation of marriage also applies customary provisions, where in the implementation of marriage there are stages that must be passed either before the marriage contract or afterwards. Customary marriage processions are believed to differ from one country to another and between one region and another. Custom in Acehnese people who want to get married, first do cah röt (pioneering the road). This activity is carried out in secret by someone who is trusted (seulangké). By approaching / talking to both families (male and female family members) until they get an agreement or not.

After cah röt, the activity is continued with meulakee. This is done when managing the cah rot is successful. Meulakee can be articulated with wooing. Meulakee was carried out openly through seulangke accompanied by several parents, geuchik parents, and teungku meunasah / imuem meunasah. This was carried out through a small ceremony called ba ranup kong haba. Seulangke is official talks about engagement by completing various applicable and promised procedures and conditions. The task is sometimes at the same time as a rotator, or sometimes separated, sometimes even at the same time carrying out the implementation. Sometimes there are separate tasks with initial assignments that are separate, and even many tasks are always at the same time with private companies.

At the ba runup ceremony, both parties decided in consultation about jeunamee (dowry), a good time for meugatip (marriage), a good time for the peuduek sandeng (inauguration), and other matters relating to the wedding event. After completing meulakee and seulangke, and all decisions in the previous activity have been carried out, meugatip (marriage) is carried out. This is a very sacred / sacred program in line with the provisions of the Sunnah of Rasul which is worth worship. The meugatip activity was then followed by the inauguration of the marriage / walimatul ursyi. Marriage inauguration is held on the day agreed upon by both parties. Usually a good day and month are chosen according to local custom. For the general public, the time is usually chosen after the rice harvest. There are also some people who choose the day and month of marriage after the month of Hajj so that none in that area is found married in the month of Hajj. This is because there is a public belief that getting married in that month can make the marriage age not last long. That is why, in determining the wedding month, the month of Hajj is called the hot moon.

The procession stage in the inauguration of the wedding includes the preparation, implementation, and completion of the day. In connection with the preparation, the dara barô side did various household preparations, festivities, boh gaca, manoe pucok bagi dara baro. The linto baro side prepares peuneuwoe linto, acara intat linto, and festivities at the same time with the program of tueng dara baro. Marriage festivity, both for linto and dara baro parties took place on the same day. In certain areas intant linto is carried out at night. However, this is usually done if the linto place is located not too far from the domicile of the dara barô. The tueng dara baro program is done a few days later and is usually women's business. The implementation of marriage and divorce during the armed conflict in Aceh can be illustrated in the following percentage forms:

Chart 4.1. Percentage of Marriage Recorded in Aceh in 1999-2005

\footnotetext{
${ }^{3}$ Wahbah Al Zuhaily, Al-Fiqh al-Islamy wa Adillatuhu, (Beirut: Dar ar-Fikr, 2003), p. vii, 71.
} 


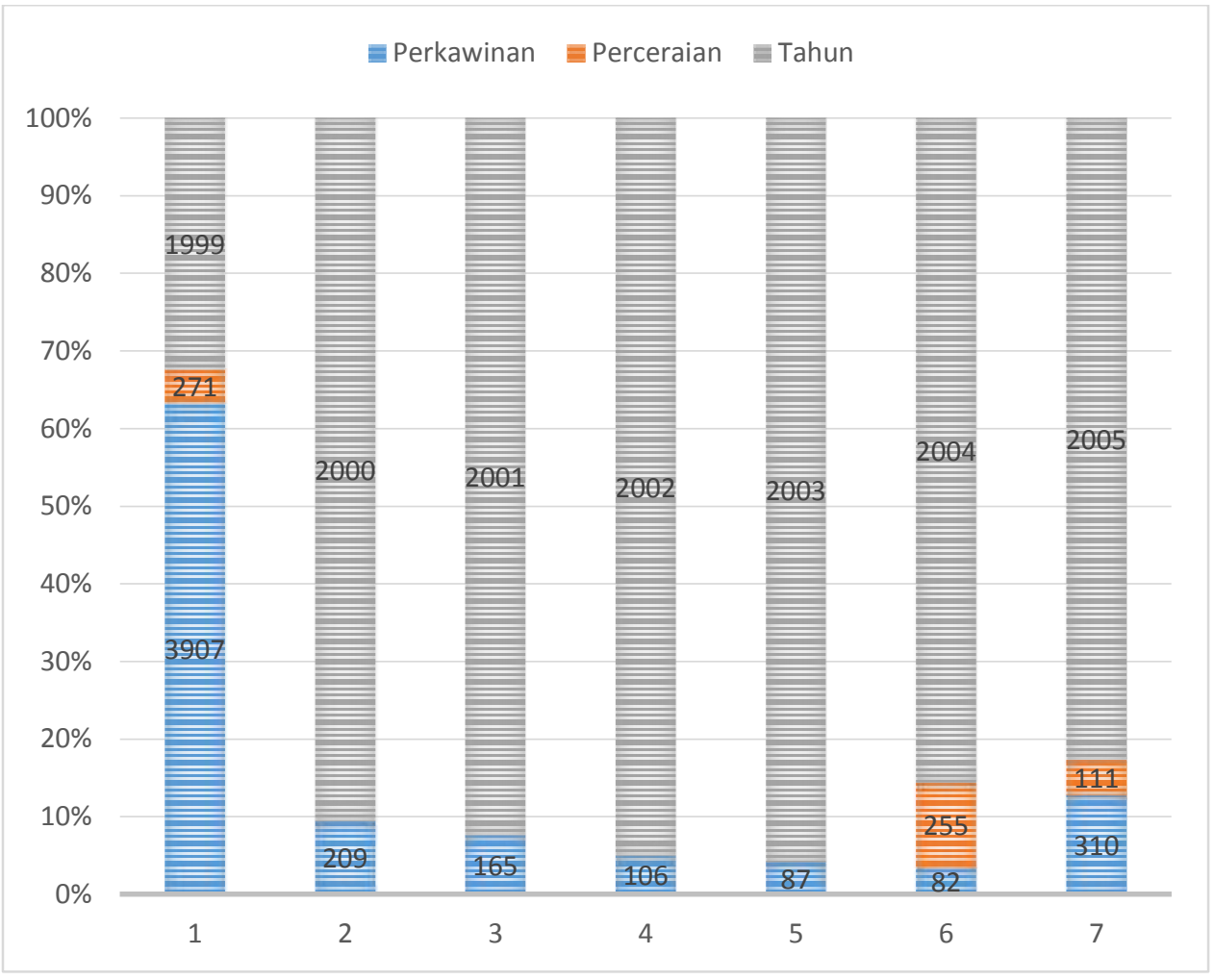

Source: Aceh Central Statistics Agency (BPS)

The graph above illustrates the implementation of marriage during the armed conflict in Aceh. Data has been taken from the Aceh Central Bureau of Statistics. The data in the graph above shows the number and percentage of marriages carried out by the community. The data includes recorded marriages and marriages that are not formally deemed by the KUA in each Regency / City in Aceh. As is known that 1999 was the beginning of the revocation of status as a Regional Military Operation (DOM) in Aceh.

In terms of the procession of customs in the process of marriage, it cannot be carried out based on the stages that have been initiated, namely beginning with the arrival of delegates from the men to get to know their families and brides, this procession is also held to interact with families and introduce themselves to the bride's family. For the second stage, it is usually continued with jak ba ranub. ${ }^{4}$ In this procession, the male family sent his envoy to visit the family of the woman by bringing souvenirs such as betel, cake and others. During the visit the envoy revealed the purpose and purpose of their arrival to the female family. If accepted, then it will be continued with deliberations with the two families and will be continued with Jak Ba Tanda. The items carried by the messenger are placed in a talam or dalong which has been decorated and handed over to the woman. On the day that had been agreed upon, a group of people from the male side came to the girl's parents' house by carrying betel as a reinforcement of the bond and its contents. After that, it will then be followed by a discussion about dowry, day and date, and invitations or guests who will come at the wedding ceremony. After the application is over, the man will beg for leave to go home and the woman's family asks for time to consult with her daughter about whether or not the application is accepted. This is as explained by the chairman of the North Aceh MPU. ${ }^{5}$

\footnotetext{
${ }^{4} \mathrm{Jak}$ ba ranub is a procession to propose brides

${ }^{5}$ Interview with Teungku H. Mustafa H. Ahmad. Chairman of the North Aceh Ulama Consultative Assembly. Date: February 6, 2018
} 
Besides the Customary order that cannot be implemented in this period, the lawsuit of the Marriage Law was neglected, namely marriage during the conflict period generally did not take place in the KUA sub-district and did not get Pre-marital guidance services. This is as stated by the Chairperson of the MPU Aceh that the marriage process during the armed conflict did not receive pre-marital guidance services nor was the registration of marriages carried out because the situation was uncertain.

However, this situation does not become an obstacle to the continuity of marriage in the Acehnese society in an orderly and orderly manner, where the marriage at this time was supervised by Imam Chik, Imam Gampong and other religious figures guided by fiqh legal provisions, as explained by the Imam Shik ${ }^{6}$ and traditional leaders. ${ }^{7}$ where the community believes that marriage based on the provisions of figh is valid even if it is not in accordance with the prevailing laws and customs, this belief is in accordance with the Fatwa of the Aceh Consultative Assembly "That the Siri Marriage is valid if it fulfills the terms and conditions", on the other the community also believes that the situation is already included in the emergency category so that marriage can be recorded without being noted, in the fiqhiyah rule it is stated "the law permits the prohibited", and the rule "avoid damage prior to reaching benefits and rules" If it is contradictory to one another then the smallest and the lightest is taken. "In the book" Mulakhas Mandhumah fiqhiyah "which is summarized by Abu Humaid Abdullah al Falasi from the book" As Sheikh Sheikh Sholeh Al Usaimin, "explained:" If there are two hazards facing each other, then take the lightest one. "

On the basis of these rules it can be understood that the people who organize marriages during the conflict have chosen smaller and lighter conditions to prevent greater danger and mafsadah and the mafsadah is to delay marriage because it cannot be recorded due to armed conflict, so it can be understood that marriage carried out during the armed conflict which only refers to the provisions of fiqh law is not defiance of national marital provisions and customary provisions but consideration of mudharat and mafsadat.

Therefore it can be argued that the organization of marriage during armed conflict generally refers only to fiqh law where in its provisions it is seen as not difficult and does not involve many other parties other than prospective husbands, prospective husbands, guardians and two witnesses who fulfill the requirements and the very basic ones are do not make the parties involved in the process of marriage unhappy in an atmosphere of armed conflict such as the national marriage law provisions that require each marriage to be recorded by the marriage registrar and customary provisions involving many parties and requiring the stages to be passed both before the marriage contract and afterwards it cannot be implemented properly considering the security situation that is not conducive and can threaten the safety of the marriage registrar official, the spouse and the community involved, so that the marriage takes place with priority to salvation even if it is not in accordance with applicable national and customary marriage law provisions.

\section{Conclusion}

Marriage during the armed conflict in Aceh was usually handled by Imum Gampong, Imam Chik and Qadi who received legitimacy from the Free Aceh Movement with a simple

\footnotetext{
${ }^{6}$ Interview with Ustadz Suhaimi. High Priest of the Mosque. Samudra Aceh Utara District Date: March 27, 2018

${ }^{7}$ Interview with Teungku Sulaiman Daud, S.H.I ..... Date: 11 February 2018.
} 
administration, besides that it was also handled by Assistant Registrar of Marriage (P3N) recruited from Imam Mesjid, Imam Gampong and leaders religion by the Head of the Office of Religious Affairs with the administration and the stages are not in accordance with the applicable legal provisions. Thus the implementation of the marriage which took place in the period between 1999 and 2005 was generally not administered in accordance with the prevailing laws and regulations because the Registrar of Marriage Officer did not dare to carry out their duties and functions as a public servant in checking the administration of marriage and recording it in accordance with the mandate, moreover the community is also afraid to deal with government offices.

\section{References}

Abd. Rahman Ghazaly. Fiqih Munakahat. Jakarta: Kencana. 2003.

Abdul Aziz Dahlan et. al, (ed) Ensiklopedi Hukum Islam (Jilid:1), Ikhtiar Baru Vanhove, Jakarta. 1996.

Abdul Rahman I, Doi, Karakteristik Hukum Islam Dan Perkawinan. Jakarta: PT. Raja Grafindo Persada. 1990.

Abdurrahman Al-Jaziri, Al-Fiqhu 'Ala Mazahib Al-Arba'ah, Maktabah Al-Jariyah, Juz 4, Kubra. Mesir. 1929.

Jalil, Husni, Teuku Ahmad Yani, and Mohd Daud Yoesoef. Implementasi Otonomi Khusus di Provinsi Aceh Berdasarkan Undang-Undang Nomor 11 Tahun 2006. Kanun: Journal of Law, Volume (12). 2 .2010.

Jamaluddin. Analisis Hukum Perkawinan terhadap Perceraian dalam Masyarakat Kota Lhokseumawe dan Kabupaten Aceh Utara, Doctoral Dissertation at the Faculty of Law, University of North Sumatra (USU). 2009.

Joseph, Suad; Nagmabadi, Afsāna (ed.). Encyclopedia of women and Islamic cultures: Family, law and politics. Brill. 2003.

Kayadibi, Saim (ed.). Ottoman Connections to the Malay World: Islam, Law and Society. The Other Press. 2011.

Lydon, Ghislaine. Inventions and Reinventions of Sharia in African History and the Recent Experiences of Nigeria, Somalia and Mali. Ufahamu: A Journal of African Studies. 2018.

Mahkamah Agung, Pedoman Teknis Administrasi dan Teknis Peradilan Agama, (Book II), Jakarta. 2010.

Mughniyah, Muhammad Jawad. Fiqih Lima Mazhab: Ja'fari, Hanafi, Maliki, Syafi'i, Hambali. Shaf, 2015.

Muhadjir Noeng. Metode Penelitian. Print-2. Alfabeta: Bandung. 2006.

Sarakhsi, Ushul as-Sarakhsi, Juz II, Lebanon: Dar al-Kutub al-Ilmiyyah, 1993.

Sarkun, Miftahurrohim N. Athār Ta'ārud Manhaj al-Fikr bayna Abū Hanīfa wa'l-Shāfi'ī'an alIstihsān Ansha'at al-Hadarat al-Islāmiyyah. Al-Jami'ah: Journal of Islamic Studies, 2013.

Sarlito Wirawan Sarwono, at el. Apa dan Bagaimana Mengatasi Problema Rumah Keluarga. 2012.

Satria Effendi M. Zein, Problematika Hukum Keluarga Islam Kontemporer (Analisis Yurisprudensi dengan Pendekatan Ushuliyah), Print-I. Jakarta: Kencana. 2004.

Sayyid Sabiq, Fiqh Munakahat, (Semarang: Dina Utama. Toha Putra Group. 1993.

Schulze, Kirsten E. The free aceh movement (GAM): Anatomy of a separatist organization. 2004.

Sedarmayanti, Putri. Manajemen Sumber Daya Manusia. Jakarta: PT. Bumi Aksara. 2007.

Shehadeh, Lamia Rustum. The legal status of married women in Lebanon. International Journal of Middle East Studies. 30. (4). 1998.

Sjamsuddin, Nazaruddin,. Revolusi di Serambi Mekah: Kisah Perjuangan Kemerdekaan dan Pertarungan Politik di Aceh 1945-1949, University of Indonesia. UI Press. Jakarta: 1999. 
Subarman, M. Nikah di bawah tangan perspektif yuridis dan sosiologis. IJTIHAD Jurnal Wacana Hukum Islam dan Kemanusiaan. 13(1). 2013.

Subhan, Z. Membina Keluarga Sakinah: PT LKiS Pelangi Aksara. 2004.

Sudarsana, I K. Teori Pertimbangan Sosial. OpenSudarsana, I K. Teori Pertimbangan Sosial". INA-Rxiv, 9 Jan. 2018.

Thoha, Miftah. Birokrasi dan Politik Indonesia. Jakarta. Rajawali Press. 2010.

Valerie J. Gilehrist, Key Informan Interviews, in books edited by Crabtree and Williem L. Miller, Doing Qualitative Research. London New Delhi: Sage Publication, 1992.

Widiasmara, Eka. Kedudukan Perkawinan dan Perceraian Dibawah Tangan di Tinjau dari Hukum Islam dan Peraturan Perundang-Undangan yang Berlaku di Indonesia. Thesis. University of Diponogoro. 2010.

Yahya Harahap, M, Hukum Perkawinan Nasional. Medan: Zahir Trading Co. 1975.

Yunus, Mahmud., Hukum Perkawinan Dalam Islam. Jakarta: Hida Karya Agung, 1959. ,. Kamus Arab-Indonesia, Jakarta: Hidakarya Agung, 1990.

Zahari Hamid, Pokok-Pokok Hukum Perkawinan Islam dan Undang-Undang Perkawinan di Indonesia. Jakarta: Bina Cipta. 1978.

Zaidah, Yusna. Isbat Nikah dalam Perspektif Kompilasi Hukum Islam Hubungannya dengan Kewenangan Peradilan Agama. Syariah Jurnal Hukum dan Pemikiran 13.1. 2014.

Zuffran Sabrie, M,. Analisa Hukum Islam Tentang Anak Luar Nikah. Jakarta: Departemen Agama RI. 1998. 